\title{
Analysis of EGFR, KRAS, and PIK3CA gene mutation rates and clinical distribution in patients with different types of lung cancer
}

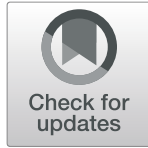

Shuo Li and Xinju Li

\begin{abstract}
Background: To analyze and evaluate EGFR, KRAS, and PIK3CA gene mutation rates and clinical distribution in patients with different types of lung cancer

Method: A total of 221 lung cancer patients treated in our hospital between January 2016 and June 2019 were enrolled. Tissue and whole blood samples were collected and analyzed to determine the mutation status of EGFR, KRAS, and PIK3CA genes. The gene exon mutation rates were determined. Relevant clinical data, such as age, gender, tumor sample type, treatment method, pathologic type, and lung cancer stage were recorded and statistically analyzed.

Results: The EGFR gene mutation rates in exons E18-E21 were 2.3\%, 17.6\%, 3.6\%, and 20.4\%, respectively. E18, E19, and E20 mutations were commonly detected in adenosquamous carcinoma, and E21 mutations were commonly detected in adenocarcinoma. Mutations in exons E18-E21 were frequently detected in patients with lung cancer stages IA, IB, IIA, or IIB, respectively. The KRAS gene mutation rate in lung cancer patients in exon E2 was higher in whole blood and tissue samples than other exon mutations, while the KRAS gene mutation rate in exons E2 and E3 was significantly higher in patients with lung cancer stages IIB and IA, respectively. PIK3CA gene mutations in exons E9 and E20 occurred in patients $<60$ years of age. Exon E9-positive mutations were more common in men or patients with squamous cell carcinoma, while exon E20-positive mutations were more common in females.

Conclusion: The EGFR, KRAS, and PIK3CA gene exon mutation rates differ and were shown to be correlated with different clinical indicators, which have significance in clinical treatment.
\end{abstract}

Keywords: Lung cancer, Gene mutation, EGFR, KRAS, PIK3CA, Clinic

\section{Background}

Lung cancer is the second most commonly diagnosed malignant cancer, with an incidence of $11.4 \%$ among all new cancer cases [1]. Lung cancer remains the leading cause of cancer deaths, with an estimated 1.8 million deaths annually [1]. Non-small cell lung cancer (NSCL C), including adenocarcinoma, squamous cell carcinoma, large cell carcinoma, adenosquamous carcinoma,

\footnotetext{
*Correspondence: lixinj2020@21cn.com

Department of Thoracic Surgery, The First Affiliated Hospital of Xi'an Jiaotong University, Xi'an 710061, Shaanxi Province, China
}

sarcomatoid carcinoma, and mucoepidermoid carcinoma, accounts for $75-80 \%$ of the total number of lung cancer cases [2]. Moreover, the prognosis is poor, and the 5-year survival rate is $<20 \%$ [2]. The mainstay of treatment for stage I-IIIa NSCLC patients is surgical resection with adjuvant chemotherapy. The National Comprehensive Cancer Network (NCCN) clinical guidelines for NSCLC recommend adjuvant chemotherapy for stage Ib-IIIa NSCLC patients after surgery [3]; however, due to individual differences and drug resistance, the effect of adjuvant chemotherapy differs. Therefore, 
individualized treatment has been proposed to achieve higher success rates than standardized treatment [4].

With the rapid advances in modern molecular biology technology, the treatment model for lung cancer has focused on targeting abnormal molecules in specific signaling pathways $[5,6]$. In the past 10 years, tyrosine kinase inhibitors (TKIs) for epidermal growth factor receptor (EGFR) have demonstrated remarkable clinical effects and paved the way for effective treatment of lung cancer [7-9]. Indeed, a recent phase III clinical trial (ADAURA [NCT02511106]) assessed the efficacy and safety of a 3rd-generation EGFR-TKI, osimertinib, which had superior efficacy when compared to EGFR-TKI (gefitinib/erlotinib) in treatment-naïve patients with EGFRmutated advanced NSCLC [10]. In addition, rapid and accurate determination of EGFR gene mutation status is important to correctly adjust the chemotherapy regimen and usage of drugs. In recent years, with the ongoing indepth studies of molecular biology and human genomics, it has been shown that EGFR-TKI treatment is effective in NSCLC patients with E19/21 EGFR mutations along with the metastases, and these patients had a longer progression-free survival (PFS) [11]. EGFR-TLI treatment of patients with KRAS mutations lacks efficacy, which indicates the different patterns of EGFR and KRAS gene mutations in lung cancer patients.

Phosphatidylinositol-3 kinase (PIK3CA) is a coding gene for the protein catalytic subunit of the phosphatidylinositol-3 kinase family (PI3Ks) [12]. It has been well-documented that activation of the PI3Ks pathway is involved in multiple human malignancies, while the effect of PIK3CA mutations on the prognosis of patients is controversial for different human cancers. It has been demonstrated that PIK3CA mutation status predicts the prognosis of breast cancer patients [13], while another study that PIK3CA mutation status is not associated with prognosis of colon cancer patients [14]. Few studies have systematically evaluated the relationship between the mutation status of EGFR, KRAS, and PIK3CA and lung cancer patients, especially among patients with different types of lung cancer.

In this study, we analyzed the mutation status of EGFR, KRAS, and PIK3CA in different types of lung cancer patients. These findings may provide theoretical insight for clinicians to make accurate and instant treatment plans for lung cancer patients.

\section{Materials and methods}

\section{General information}

A total of 221 lung cancer patients (114 males [51.6\%] and 107 females [48.4\%]) who were treated in our hospital from January 2016 to June 2019 were enrolled in the current study. The following specimens were collected: 194 tissue samples (87.7\%), 22 whole blood samples (10.0\%), and 5 whole blood + tissue samples (2.3\%). One hundred twelve patients $(50.7 \%)$ were $\leq 60$ years of age, $109(49.3 \%)$ were $>60$ years of age, and the average age was $59.62 \pm 9.82$ years. The clinical characteristics of the patients are presented in Table 1. All paraffin-embedded tissue sections and cytologic smears were examined and diagnosed by senior pathologists. The tumor areas were delineated, and the tumor cell number ( $>200)$ and percentage (> 20\%) were evaluated. Ten milliliters of peripheral venous blood samples was collected in blood collection tubes dedicated to protect free DNA for normal temperature transportation and preservation.

\section{Reagents}

Formaldehyde-fixed, paraffin-embedded tissue DNA extraction kits were purchased from Qiagen Company (Darmstadt, Germany). Tissue DNA extraction kits, plasma circulating DNA extraction kits, human EGFR gene mutation detection kits (ARMS method [15]), and human EGFR, KRAS, and PIK3CA gene mutation detection kits (super-ARMS method [16]) were purchased from AmoyDx (Xiamen, China). An ABI fluorescence quantitative PCR instrument (Foster city, CA, USA) was used.

Table 1 Clinical characteristics of patients enrolled in this study

\begin{tabular}{lll}
\hline Characteristics & & Number (\%) \\
\hline Age (year) & $59.62 \pm 9.82$ & 221 \\
& $\leq 60$ & $112(50.7)$ \\
Gender & $>60$ & $109(49.3)$ \\
& Male & $114(51.6)$ \\
Pathological type & Female & $107(48.4)$ \\
& Squamous cell carcinoma & $15(6.8)$ \\
& Adenocarcinoma & $155(70.1)$ \\
& Adenosquamous carcinoma & $7(3.2)$ \\
Staging & Others & $44(19.9)$ \\
& Stage IA & $22(10.0)$ \\
& Stage IB & $51(23.1)$ \\
& Stage IIA & $8(3.6)$ \\
& Stage IIB & $9(4.1)$ \\
& Stage IIIA & $23(10.4)$ \\
& Stage IIIB & $5(2.3)$ \\
& Stage IV & $33(14.9)$ \\
& Undefined & $70(31.7)$ \\
& Surgery & $67(30.3)$ \\
& Chemotherapy & $37(16.7)$ \\
& Surgery + chemotherapy & $66(30.0)$ \\
& Not available & $51(23.0)$ \\
\hline
\end{tabular}


Detection of EGFR, KRAS, and PIK3CA gene mutations Sample processing and DNA extraction were performed according to the manufacturer's protocol. The DNA extraction protocol from paraffin-tissue samples was as follows: refrigerate the circled wax block and place the block on a slicer, cut the samples into 10 pieces (4- $\mu \mathrm{m}$-thick slices), remove the non-cancerous tissue, and transfer the wax into a 2-ml centrifuge tube. Extract $50 \mu \mathrm{l}$ of DNA according to the formaldehyde-fixed, paraffin-embedded tissue DNA extraction kit protocol. The DNA extraction from peripheral blood sample protocol was as follows: collect the samples and centrifuge the samples immediately at $2000 \times g$ for $10 \mathrm{~min}$, aspirate the supernatant and transfer the sample to a new centrifuge tube, centrifuge the samples at $8000 \times g$ for $10 \mathrm{~min}$, and aspirate the supernatant and transfer to a new centrifuge tube. PBS was added to the tube if the volume was $<4 \mathrm{ml}$, and $100 \mu \mathrm{l}$ of DNA was extracted according to the plasma circulating DNA extraction kit protocol.

The EGFR (E18, E19, E20, and E21), KRAS (E2, E3, and $\mathrm{E} 4$ ), and PIK3CA (E9 and E20) gene mutations in lung cancer samples were detected using liquid chip technology. The main research steps were as follows: the gene fragments containing common alleles in the exons of EGFR, KRAS, and PIK3CA genes were obtained using multiplex PCR; the reaction products were hydrolyzed by an exonuclease and alkaline phosphatase (EXO-SAP); the allele-specific primer extension (ASPE) was used for PCR product processing; the tag sequence on the amplified product and anti-tag sequence on polystyrene microspheres were specifically hybridized; and the hybridized product was analyzed using a Luminex 200 system (Austin, TX, USA) to obtain the median fluorescence value (MFI).

\section{Statistical analysis}

The SPSS 19.0 software was used for statistical analyses. The correlation between EGFR, KRAS, and PIK3CA gene mutations and clinicopathologic features of patients was analyzed using unpaired $x^{2}$ tests or Fisher exact probability analysis [17]. The difference was statistically significant $(\mathrm{p}<0.05)$.

\section{Results}

Detection and analysis of EGFR gene mutations

As shown in Table 2, mutation of the EGFR gene in exon E18 was significantly related to sample type,

Table 2 Relationship between mutation of EGFR gene in exon E18 and clinical parameters

\begin{tabular}{|c|c|c|c|c|c|c|c|}
\hline & \multirow[t]{2}{*}{ Clinical parameters } & \multirow[t]{2}{*}{ No. } & \multicolumn{2}{|l|}{ EGFR-E18 } & \multirow{2}{*}{$\begin{array}{l}\text { Positive } \\
\text { rate (\%) }\end{array}$} & \multirow[t]{2}{*}{$x^{2}$} & \multirow{2}{*}{$\begin{array}{l}p \\
\text { value }\end{array}$} \\
\hline & & & Wild type & Mutant type & & & \\
\hline \multirow[t]{2}{*}{ Age } & $\leq 60$ & 112 & 93 & 1 & 0.89 & 4.067 & 0.131 \\
\hline & $>60$ & 109 & 95 & 4 & 3.67 & & \\
\hline \multirow[t]{2}{*}{ Gender } & Male & 114 & 97 & 1 & 0.88 & 2.344 & 0.310 \\
\hline & Female & 107 & 91 & 4 & 3.74 & & \\
\hline \multirow[t]{3}{*}{ Sample type } & Tissue sample & 194 & 178 & 5 & 2.58 & 73.377 & $<0.001$ \\
\hline & Whole blood sample & 22 & 7 & 0 & 0 & & \\
\hline & Whole blood + tissue sample & 5 & 3 & 0 & 0 & & \\
\hline \multirow[t]{3}{*}{ Pathological type } & Squamous cell carcinoma & 15 & 10 & 0 & 0 & 16.489 & 0.011 \\
\hline & Adenocarcinoma & 155 & 138 & 4 & 2.58 & & \\
\hline & Adenosquamous carcinoma & 7 & 5 & 1 & 14.29 & & \\
\hline \multirow[t]{7}{*}{ Staging } & Stage IA & 22 & 19 & 3 & 13.64 & 40.276 & $<0.001$ \\
\hline & Stage IB & 51 & 48 & 1 & 1.96 & & \\
\hline & Stage IIA & 8 & 7 & 1 & 12.50 & & \\
\hline & Stage IIB & 9 & 8 & 0 & 0 & & \\
\hline & Stage IIIA & 23 & 20 & 0 & 0 & & \\
\hline & Stage IIIB & 5 & 2 & 0 & 0 & & \\
\hline & Stage IV & 33 & 28 & 0 & 0 & & \\
\hline \multirow[t]{3}{*}{ Treatment } & Surgery & 67 & 61 & 4 & 5.97 & 20.081 & 0.003 \\
\hline & Chemotherapy & 37 & 28 & 0 & 0 & & \\
\hline & Surgery + chemotherapy & 66 & 59 & 1 & 1.52 & & \\
\hline
\end{tabular}


pathologic type, lung cancer stage, and treatment method. The E18 mutation was mainly detected in tissue samples (2.58\%) and adenosquamous carcinoma (14.29\%). In addition, stage IA lung cancer patients (13.64\%) and patients who underwent surgical resection (5.97\%) were diagnosed with a higher E18 mutation rate; however, there was no significant difference between the E19 and E20 mutation status and clinical indicators (Tables 3 and 4). The E19-positive mutation rate was higher in adenosquamous carcinoma $(25.49 \%)$ and stage IB patients (28.57\%), while the E20-positive mutation rate was higher in adenosquamous carcinoma (14.29\%) and stage IIIB stage patients (20.00\%).

As shown in Table 5, mutation of the EGFR gene in exon E21 was significantly associated with gender, lung cancer stage, and treatment method. Specifically, the E21-positive mutation rate in females (29.91\%) was significantly higher than males (11.40\%), and the E21 mutation rate in patients with stage IB lung cancer (33.33\%) was significantly higher than other stages. Like the E18 mutation rate, the patients who underwent surgical resection (37.31\%) had a higher E18 mutation rate than patients who were treated with chemotherapy (10.81\%) or surgical resection combined with chemotherapy (13.64\%). Even though there was no significant difference between pathologic type and the E21-positive mutation rate, the results showed that the patients with adenocarcinoma had the highest E21 mutation rate $(24.52 \%)$.

\section{Detection and analysis of KRAS gene mutations}

As shown in Table 6, mutation of the KRAS gene in exon E2 was significantly related to sample type. In contrast to mutation of the EGFR gene in exon E18, the E2-positive KRAS mutation rate in the whole blood + tissue sample (20.00\%) was significantly higher than the whole blood $(0 \%)$ or tissue sample (7.22\%). There was no significant difference between the E2 mutation rate and other clinical indicators. Patients with adenosquamous carcinoma (14.29\%) and patients with stage IIB lung cancer (11.11\%) had a higher E2 mutation rate in the KRAS gene. Similar to mutation of the EGFR gene in exons E20 and E21, there was no significant difference between the KRAS gene mutation rate in exon E3 and clinical indicators (Table 7). The E3-positive mutation rate was more common in adenocarcinoma patients (0.65\%) and

Table 3 Relationship between mutation of EGFR gene in exon E19 and clinical parameters

\begin{tabular}{|c|c|c|c|c|c|c|c|}
\hline & \multirow[t]{2}{*}{ Clinical parameters } & \multirow[t]{2}{*}{ No. } & \multicolumn{2}{|l|}{ EGFR-E19 } & \multirow{2}{*}{$\begin{array}{l}\text { Positive } \\
\text { rate (\%) }\end{array}$} & \multirow[t]{2}{*}{$x^{2}$} & \multirow{2}{*}{$\begin{array}{l}p \\
\text { value }\end{array}$} \\
\hline & & & Wild type & Mutant type & & & \\
\hline \multirow[t]{2}{*}{ Age } & $\leq 60$ & 112 & 85 & 24 & 21.43 & 2.241 & 0.326 \\
\hline & $>60$ & 109 & 91 & 15 & 13.76 & & \\
\hline \multirow[t]{2}{*}{ Gender } & Male & 114 & 96 & 14 & 12.28 & 5.007 & 0.082 \\
\hline & Female & 107 & 80 & 25 & 23.36 & & \\
\hline \multirow[t]{3}{*}{ Sample type } & Tissue sample & 194 & 155 & 34 & 17.53 & 2.020 & 0.732 \\
\hline & Whole blood sample & 22 & 16 & 5 & 22.73 & & \\
\hline & Whole blood + tissue sample & 5 & 5 & 0 & 0 & & \\
\hline \multirow[t]{3}{*}{ Pathological type } & Squamous cell carcinoma & 15 & 14 & 0 & 0 & 10.285 & 0.113 \\
\hline & Adenocarcinoma & 155 & 125 & 28 & 18.06 & & \\
\hline & Adenosquamous carcinoma & 7 & 4 & 2 & 28.57 & & \\
\hline \multirow[t]{7}{*}{ Staging } & Stage IA & 22 & 18 & 4 & 18.18 & 20.438 & 0.117 \\
\hline & Stage IB & 51 & 38 & 13 & 25.49 & & \\
\hline & Stage IIA & 8 & 8 & 0 & 0 & & \\
\hline & Stage $\| B$ & 9 & 7 & 1 & 11.11 & & \\
\hline & Stage IIIA & 23 & 19 & 2 & 8.70 & & \\
\hline & Stage IIIB & 5 & 4 & 0 & 0 & & \\
\hline & Stage IV & 33 & 28 & 5 & 15.15 & & \\
\hline \multirow[t]{3}{*}{ Treatment } & Surgery & 67 & 52 & 14 & 20.90 & 3.313 & 0.769 \\
\hline & Chemotherapy & 37 & 31 & 5 & 13.51 & & \\
\hline & Surgery + chemotherapy & 66 & 54 & 9 & 13.64 & & \\
\hline
\end{tabular}

Data are adjusted for age, gender, sample type, pathological type, staging, and treatment method 
Table 4 Relationship between mutation of EGFR gene in exon E20 and clinical parameters

\begin{tabular}{|c|c|c|c|c|c|c|c|}
\hline & \multirow[t]{2}{*}{ Clinical parameters } & \multirow[t]{2}{*}{ No. } & \multicolumn{2}{|l|}{ EGFR-E20 } & \multirow{2}{*}{$\begin{array}{l}\text { Positive } \\
\text { rate (\%) }\end{array}$} & \multirow[t]{2}{*}{$x^{2}$} & \multirow{2}{*}{$\begin{array}{l}p \\
\text { value }\end{array}$} \\
\hline & & & Wild type & Mutant type & & & \\
\hline \multirow[t]{2}{*}{ Age } & $\leq 60$ & 112 & 104 & 5 & 4.46 & 1.538 & 0.463 \\
\hline & $>60$ & 109 & 100 & 3 & 2.75 & & \\
\hline \multirow[t]{2}{*}{ Gender } & Male & 114 & 103 & 4 & 3.51 & 2.578 & 0.276 \\
\hline & Female & 107 & 101 & 4 & 3.74 & & \\
\hline \multirow[t]{3}{*}{ Sample type } & Tissue sample & 194 & 178 & 8 & 4.12 & 1.392 & 0.845 \\
\hline & Whole blood sample & 22 & 21 & 0 & 0 & & \\
\hline & Whole blood + tissue sample & 5 & 5 & 0 & 0 & & \\
\hline \multirow[t]{3}{*}{ Pathological type } & Squamous cell carcinoma & 15 & 13 & 0 & 0 & 9.188 & 0.163 \\
\hline & Adenocarcinoma & 155 & 146 & 5 & 3.23 & & \\
\hline & Adenosquamous carcinoma & 7 & 5 & 1 & 14.29 & & \\
\hline \multirow[t]{7}{*}{ Staging } & Stage IA & 22 & 22 & 0 & 0 & 17.414 & 0.235 \\
\hline & Stage IB & 51 & 48 & 2 & 3.92 & & \\
\hline & Stage IIA & 8 & 7 & 1 & 12.50 & & \\
\hline & Stage $\| B$ & 9 & 8 & 0 & 0 & & \\
\hline & Stage IIIA & 23 & 21 & 0 & 0 & & \\
\hline & Stage IIIB & 5 & 3 & 1 & 20.00 & & \\
\hline & Stage IV & 33 & 32 & 1 & 3.03 & & \\
\hline \multirow[t]{3}{*}{ Treatment } & Surgery & 67 & 63 & 2 & 2.99 & 2.131 & 0.907 \\
\hline & Chemotherapy & 37 & 34 & 1 & 2.70 & & \\
\hline & Surgery + chemotherapy & 66 & 59 & 4 & 6.06 & & \\
\hline
\end{tabular}

Data are adjusted for age, gender, sample type, pathological type, staging, and treatment method

patients with stage IA lung cancer (4.55\%). Interestingly, there were no positive mutations of the KRAS gene in exon E4 detected in samples collected from the current study (Table 8).

\section{Detection and analysis of PIK3CA gene mutations}

As shown in Table 9, mutation of the PIK3CA gene in exon E9 was significantly related to the sample and pathologic types. The positive E9 mutation rates in the whole blood + tissue sample $(20.00 \%)$ and patients with squamous cell carcinoma (13.33\%) were the highest. In addition, E9-positive mutations were more common in stage IIB lung cancer patients (11.11\%) and patients treated with chemotherapy (5.41\%). The mutation status of the PIK3CA gene in exon E20 was significantly associated with sample type (Table 10). The rate of positive E20 mutations in the whole blood sample (4.55\%) was significantly higher than the other two sample types; however, there were no positive PIK3CA gene mutations detected in exon E20 among patients with different pathologic types or lung cancer stages (Table 10).

\section{Discussion}

The collective evidence has demonstrated that targeting abnormal genes in specific signaling pathways is a significant and effective strategy to eliminate cancers $[18,19]$. In this study, we found that mutations of the EGFR gene in exons E18, E19, and E20 in lung cancer patients were common in adenosquamous carcinoma, while E21 mutations were common in adenocarcinoma. The E18 and E21 mutation rates were associated with lung cancer stage, gender, sample type, and treatment modality. Similarly, the KRAS gene mutation rate in exons E2 and E4 were also correlated with the sample type and treatment approach. In addition, the PIK3CA gene mutation status in exons E9 and E20 was associated with sample type, as well as lung cancer type. Taken together, these findings provide theoretical insight for clinicians to make accurate and timely treatment plans for lung cancer patients.

EGFR is a transmembrane tyrosine kinase receptor that plays an important role in the growth, proliferation, and differentiation of cells under physiologic and pathologic conditions. It has been reported that 
Table 5 Relationship between mutation of EGFR gene in exon E21 and clinical parameters

\begin{tabular}{|c|c|c|c|c|c|c|c|}
\hline & Clinical parameters & No. & EGFR-E21 & & Positive & $x^{2}$ & $\mathrm{p}$ \\
\hline & & & Wild type & Mutant type & rate $(\%)$ & & value \\
\hline Age & $\leq 60$ & 112 & 84 & 24 & 21.43 & 0.159 & 0.923 \\
\hline & $>60$ & 109 & 84 & 21 & 19.27 & & \\
\hline Gender & Male & 114 & 96 & 13 & 11.40 & 11.741 & 0.003 \\
\hline & Female & 107 & 72 & 32 & 29.91 & & \\
\hline Sample type & Tissue sample & 194 & 142 & 45 & 23.20 & 8.171 & 0.086 \\
\hline & Whole blood sample & 22 & 21 & 0 & 0 & & \\
\hline & Whole blood + tissue sample & 5 & 5 & 0 & 0 & & \\
\hline Pathological type & Squamous cell carcinoma & 15 & 14 & 0 & 0 & 9.627 & 0.141 \\
\hline & Adenocarcinoma & 155 & 113 & 38 & 24.52 & & \\
\hline & Adenosquamous carcinoma & 7 & 5 & 1 & 14.29 & & \\
\hline Staging & Stage IA & 22 & 15 & 7 & 31.82 & 26.220 & 0.024 \\
\hline & Stage IB & 51 & 33 & 17 & 33.33 & & \\
\hline & Stage IIA & 8 & 7 & 1 & 12.50 & & \\
\hline & Stage IIB & 9 & 8 & 0 & 0 & & \\
\hline & Stage IIIA & 23 & 14 & 7 & 30.43 & & \\
\hline & Stage IIIB & 5 & 4 & 0 & 0 & & \\
\hline & Stage IV & 33 & 27 & 6 & 18.18 & & \\
\hline Treatment & Surgery & 67 & 40 & 25 & 37.31 & 18.020 & 0.006 \\
\hline & Chemotherapy & 37 & 31 & 4 & 10.81 & & \\
\hline & Surgery + chemotherapy & 66 & 54 & 9 & 13.64 & & \\
\hline
\end{tabular}

Data are adjusted for age, gender, sample type, pathological type, staging, and treatment method

Table 6 Relationship between mutation of KRAS gene in exon E2 and clinical parameters

\begin{tabular}{|c|c|c|c|c|c|c|c|}
\hline & Clinical parameters & No. & KRAS-E2 & & Positive & $x^{2}$ & $p$ \\
\hline & & & Wild type & Mutant type & rate $(\%)$ & & value \\
\hline Age & $\leq 60$ & 112 & 79 & 8 & 7.14 & 0.207 & 0.902 \\
\hline & $>60$ & 109 & 75 & 7 & 6.42 & & \\
\hline Gender & Male & 114 & 78 & 11 & 9.65 & 3.151 & 0.207 \\
\hline & Female & 107 & 76 & 4 & 3.74 & & \\
\hline Sample type & Tissue sample & 194 & 129 & 14 & 7.22 & 10.462 & 0.033 \\
\hline & Whole blood sample & 22 & 21 & 0 & 0 & & \\
\hline & Whole blood + tissue sample & 5 & 4 & 1 & 20.00 & & \\
\hline Pathological type & Squamous cell carcinoma & 15 & 12 & 0 & 0 & 5.415 & 0.492 \\
\hline & Adenocarcinoma & 155 & 104 & 10 & 6.45 & & \\
\hline & Adenosquamous carcinoma & 7 & 4 & 1 & 14.29 & & \\
\hline Staging & Stage IA & 22 & 16 & 0 & 0 & 10.624 & 0.715 \\
\hline & Stage IB & 51 & 33 & 5 & 9.80 & & \\
\hline & Stage IIA & 8 & 6 & 0 & 0 & & \\
\hline & Stage IIB & 9 & 7 & 1 & 11.11 & & \\
\hline & Stage IIIA & 23 & 16 & 0 & 0 & & \\
\hline & Stage IIIB & 5 & 4 & 0 & 0 & & \\
\hline & Stage IV & 33 & 27 & 2 & 6.06 & & \\
\hline Treatment & Surgery & 67 & 48 & 4 & 5.97 & 2.406 & 0.879 \\
\hline & Chemotherapy & 37 & 25 & 1 & 2.70 & & \\
\hline & Surgery + chemotherapy & 66 & 45 & 6 & 9.09 & & \\
\hline
\end{tabular}


Table 7 Relationship between mutation of KRAS gene in exon E3 and clinical parameters

\begin{tabular}{|c|c|c|c|c|c|c|c|}
\hline & \multirow[t]{2}{*}{ Clinical parameters } & \multirow[t]{2}{*}{ No. } & \multicolumn{2}{|l|}{ KRAS-E3 } & \multirow{2}{*}{$\begin{array}{l}\text { Positive } \\
\text { rate (\%) }\end{array}$} & \multirow[t]{2}{*}{$x^{2}$} & \multirow{2}{*}{$\begin{array}{l}p \\
\text { value }\end{array}$} \\
\hline & & & Wild type & Mutant type & & & \\
\hline \multirow[t]{2}{*}{ Age } & $\leq 60$ & 112 & 85 & 1 & 0.89 & 0.075 & 0.963 \\
\hline & $>60$ & 109 & 81 & 1 & 0.92 & & \\
\hline \multirow[t]{2}{*}{ Gender } & Male & 114 & 87 & 1 & 0.88 & 0.183 & 0.913 \\
\hline & Female & 107 & 79 & 1 & 0.93 & & \\
\hline \multirow[t]{3}{*}{ Sample type } & Tissue sample & 194 & 140 & 2 & 1.03 & 7.436 & 0.115 \\
\hline & Whole blood sample & 22 & 21 & 0 & 0 & & \\
\hline & Whole blood + tissue sample & 5 & 5 & 0 & 0 & & \\
\hline \multirow[t]{3}{*}{ Pathological type } & Squamous cell carcinoma & 15 & 12 & 0 & 0 & 3.399 & 0.757 \\
\hline & Adenocarcinoma & 155 & 113 & 1 & 0.65 & & \\
\hline & Adenosquamous carcinoma & 7 & 5 & 0 & 0 & & \\
\hline \multirow[t]{7}{*}{ Staging } & Stage IA & 22 & 15 & 1 & 4.55 & 9.357 & 0.808 \\
\hline & Stage IB & 51 & 38 & 0 & 0 & & \\
\hline & Stage IIA & 8 & 6 & 0 & 0 & & \\
\hline & Stage $\| B$ & 9 & 8 & 0 & 0 & & \\
\hline & Stage IIIA & 23 & 16 & 0 & 0 & & \\
\hline & Stage IIIB & 5 & 4 & 0 & 0 & & \\
\hline & Stage IV & 33 & 29 & 0 & 0 & & \\
\hline \multirow[t]{3}{*}{ Treatment } & Surgery & 67 & 51 & 1 & 1.49 & 2.612 & 0.856 \\
\hline & Chemotherapy & 37 & 26 & 0 & 0 & & \\
\hline & Surgery + chemotherapy & 66 & 51 & 0 & 0 & & \\
\hline
\end{tabular}

Data are adjusted for age, gender, sample type, pathological type, staging, and treatment method

the EGFR mutation rate is $30-40 \%$ in Asian lung cancer patients [20] and $10-15 \%$ in European Caucasian patients [21]. Targeted therapies with EGFRTKIs, such as gefitinib, erlotinib, and afatinib, have been well-established to effectively treat EGFR mutant NSCLC [22]; however, not all EGFR mutations are sensitive to EGFR-TKI treatment. For example, lung cancer cells with EGFR gene mutations in exons E19 and E21 are more sensitive to EGFR-TKImediated cell apoptosis, while cells with a mutation in exon 20 have increased resistance to EGFR-TKImediated cell apoptosis [23]. In addition, a recent 3rd-generation EGFR-TKI, osimertinib, had a statistically significant and clinically meaningful improvement in disease-free survival in patients with common sensitive EGFR-mutated NSCLC after complete tumor resection and adjuvant chemotherapy $[10,24]$. Therefore, detection of EGFR mutation status in NSCLC patients before treatment is of great importance in the clinical setting. In this study, the positive EGFR mutation rates in exons E18-E21 were $2.3 \%, 17.6 \%, 3.6 \%$, and $20.4 \%$ respectively.
Mutations in exons E19 and E21 represented the vast majority (87\%) of all observed EGFR gene mutations in lung cancer patients, which is consistent with another study [25]. Interestingly, the mutation rates in exons E18-E21 were significantly different in patients with stages IA, IB, IIA, or IIB, respectively. Nie et al. [26] reported that stage I lung adenocarcinoma patients had the highest incidence of mutations when compared with other pathologic stages [26], which was consistent with our finding. In addition, even though there was no statistical difference between the E19-E21 mutation status and patient gender or age, females and patients $\leq 60$ years of age had a higher mutation rate than males, females, and patients $>60$ years of age, which was in agreement with the dominant population of EGFR mutations in females [24] and young patients [27].

KRAS mutations are key oncogenic regulators in the development of many human malignant cancers, including lung cancer. KRAS mutations regulate signal transduction networks, which are necessary for cell survival, proliferation, differentiation, and 
Table 8 Relationship between mutation of KRAS gene in exon E4 and clinical parameters

\begin{tabular}{|c|c|c|c|c|c|c|c|}
\hline & \multirow[t]{2}{*}{ Clinical parameters } & \multirow[t]{2}{*}{ No. } & \multicolumn{2}{|l|}{ KRAS-E4 } & \multirow{2}{*}{$\begin{array}{l}\text { Positive } \\
\text { rate (\%) }\end{array}$} & \multirow[t]{2}{*}{$x^{2}$} & \multirow{2}{*}{$\begin{array}{l}\mathrm{p} \\
\text { value }\end{array}$} \\
\hline & & & Wild type & Mutant type & & & \\
\hline \multirow[t]{2}{*}{ Age } & $\leq 60$ & 112 & 58 & 0 & 0 & 2.998 & 0.103 \\
\hline & $>60$ & 109 & 69 & 0 & 0 & & \\
\hline \multirow[t]{2}{*}{ Gender } & Male & 114 & 70 & 0 & 0 & 1.493 & 0.276 \\
\hline & Female & 107 & 57 & 0 & 0 & & \\
\hline \multirow[t]{3}{*}{ Sample type } & Tissue sample & 194 & 120 & 0 & 0 & 15.433 & $<0.001$ \\
\hline & Whole blood sample & 22 & 4 & 0 & 0 & & \\
\hline & Whole blood + tissue sample & 5 & 3 & 0 & 0 & & \\
\hline \multirow[t]{3}{*}{ Pathological type } & Squamous cell carcinoma & 15 & 9 & 0 & 0 & 0.047 & 0.997 \\
\hline & Adenocarcinoma & 155 & 89 & 0 & 0 & & \\
\hline & Adenosquamous carcinoma & 7 & 4 & 0 & 0 & & \\
\hline \multirow[t]{7}{*}{ Staging } & Stage IA & 22 & 13 & 0 & 0 & 8.274 & 0.309 \\
\hline & Stage IB & 51 & 34 & 0 & 0 & & \\
\hline & Stage IIA & 8 & 5 & 0 & 0 & & \\
\hline & Stage IIB & 9 & 8 & 0 & 0 & & \\
\hline & Stage IIIA & 23 & 13 & 0 & 0 & & \\
\hline & Stage IIIB & 5 & 2 & 0 & 0 & & \\
\hline & Stage IV & 33 & 16 & 0 & 0 & & \\
\hline \multirow[t]{3}{*}{ Treatment } & Surgery & 67 & 45 & 0 & 0 & 8.807 & 0.032 \\
\hline & Chemotherapy & 37 & 17 & 0 & 0 & & \\
\hline & Surgery + chemotherapy & 66 & 42 & 0 & 0 & & \\
\hline
\end{tabular}

Data are adjusted for age, gender, sample type, pathological type, staging, and treatment method

apoptosis [28, 29]. Mutated KRAS leads to phosphorylation and activation of p21. Approximately $29 \%$ of NSCLC patients have KRAS gene mutations, among whom those with adenocarcinoma and a history of smoking are the most commonly diagnosed [30]. Collective evidence has demonstrated that the KRAS gene mutation status serves as a biomarker to predict the prognosis of NSCLC patients after chemotherapy [31]; however, KRAS and EGFR mutations are mutually exclusive, and NSCLC patients with KRAS mutations have a low response rate to EGFR-TKIs [32]. At present, several KRAS-targeting drugs, such as heat shock protein 90 (Hsp90) inhibitors, have been used in the treatment of NSCLC patients with KRAS-positive mutations with significant efficacy [33]. Therefore, except for detection of the EGFR gene, confirmation of KRAS gene mutation status is also important in the clinical setting.

In this study, it was shown that the positive KRAS gene mutation rate in exon E2 was highest in whole blood + tissue samples, patients with stage IIB, and patients with adenosquamous carcinoma; however, patients with adenocarcinoma or stage IA lung cancer were significantly more frequent than other lung cancer types or stages. Notably, no E4-positive mutations were detected in this study, which might reflect the limited sample size.

PI3Ks play a vital role in many biological processes and can activate serine/threonine kinase Akt and the downstream mTOR pathway to regulate cell survival, proliferation, and the cell cycle. Somatic mutations in the PI3K-Akt-mTOR pathway are often found in cancer tumorigenesis and can be used as a target for treatment of cancer patients [34]. PI3Ks consist of catalytic (P110) and regulatory subunits (p85), while catalytic subunits contain 3 gene codes (PIK3CA, PIK3CB, and PIK3CD). Generally, PIK3CA is the most common mutation location in cancer patients [35]. The most common mutation sites of PIK3CA are located in the spiral domain, including E542K and $\mathrm{E} 545 \mathrm{~K}$ in exon 9, and in the kinase domain, including H1047R in exon 20 [36]. In this study, we found that PIK3CA-E9 and the E20-positive mutation rates were higher in patients $\leq 60$ years of age. 
Table 9 Relationship between mutation of PIK3CA gene in exon E9 and clinical parameters

\begin{tabular}{|c|c|c|c|c|c|c|c|}
\hline & \multirow[t]{2}{*}{ Clinical parameters } & \multirow[t]{2}{*}{ No. } & \multicolumn{2}{|l|}{ PIK3CA-E9 } & \multirow{2}{*}{$\begin{array}{l}\text { Positive } \\
\text { rate (\%) }\end{array}$} & \multirow[t]{2}{*}{$x^{2}$} & \multirow{2}{*}{$\begin{array}{l}\mathrm{p} \\
\text { value }\end{array}$} \\
\hline & & & Wild type & Mutant type & & & \\
\hline \multirow[t]{2}{*}{ Age } & $\leq 60$ & 112 & 82 & 3 & 2.68 & 1.087 & 0.581 \\
\hline & $>60$ & 109 & 79 & 1 & 0.92 & & \\
\hline \multirow[t]{2}{*}{ Gender } & Male & 114 & 82 & 4 & 3.51 & 3.838 & 0.147 \\
\hline & Female & 107 & 79 & 0 & 0 & & \\
\hline \multirow[t]{3}{*}{ Sample type } & Tissue sample & 194 & 139 & 2 & 1.03 & 13.773 & 0.008 \\
\hline & Whole blood sample & 22 & 18 & 1 & 4.55 & & \\
\hline & Whole blood + tissue sample & 5 & 4 & 1 & 20.00 & & \\
\hline \multirow[t]{3}{*}{ Pathological type } & Squamous cell carcinoma & 15 & 10 & 2 & 13.33 & 13.353 & 0.038 \\
\hline & Adenocarcinoma & 155 & 112 & 1 & 0.65 & & \\
\hline & Adenosquamous carcinoma & 7 & 5 & 0 & 0 & & \\
\hline \multirow[t]{7}{*}{ Staging } & Stage IA & 22 & 16 & 0 & 0 & 10.663 & 0.712 \\
\hline & Stage IB & 51 & 36 & 1 & 1.96 & & \\
\hline & Stage IIA & 8 & 6 & 0 & 0 & & \\
\hline & Stage $\| B$ & 9 & 7 & 1 & 11.11 & & \\
\hline & Stage IIIA & 23 & 16 & 0 & 0 & & \\
\hline & Stage IIIB & 5 & 4 & 0 & 0 & & \\
\hline & Stage IV & 33 & 28 & 1 & 3.03 & & \\
\hline \multirow[t]{3}{*}{ Treatment } & Surgery & 67 & 52 & 0 & 0 & 5.112 & 0.530 \\
\hline & Chemotherapy & 37 & 24 & 2 & 5.41 & & \\
\hline & Surgery + chemotherapy & 66 & 49 & 1 & 1.52 & & \\
\hline
\end{tabular}

Data are adjusted for age, gender, sample type, pathological type, staging, and treatment method

E9-positive mutations were more common in males, while E20-positive mutations were more common in females. In addition, the positive PIK3CA-E9 mutation rate was highest in whole blood + tissue samples and patients with squamous cell carcinoma, while the E20 mutation was highest in whole blood samples.

The current study showed that the positive mutation rates in EGFR, KRAS, and PIK3CA gene exon loci were different which had a correlation with different clinical indicators. These findings may provide significance for the direction and predictability of clinical lung cancer treatment. With respect to the diagnosis and treatment of lung cancer, further understanding of these biomarkers can be used to assess the risk of tumor occurrence, early diagnosis, formulation of treatment plan, and evaluation of patient prognosis. In recent years, because the importance of biomarkers has been gradually revealed by scientists, more and more new biomarkers have been investigated and applied in the clinical setting. Therefore, better illustrating the significance of each biomarker in the diagnosis, treatment, and prognosis of lung cancer could potentially reduce the mistakes made in the early diagnosis of cancer patients and improve the efficacy of personalized treatment plans for cancer patients.

There were some limitations in this study. First, this was a single-center study with a small size of patients with lung cancer. Second, there were few patients with KRAS gene mutations in exons E3 $(n=2)$ and E4 $(n=0)$ or with PIK3CA gene mutations in exon E20 $(n=1)$, which may result in inaccurate conclusions for these cohorts. Therefore, further investigations with a large sample size, as well as a comparison of samples in multiple centers, are needed to confirm the current findings. Third, the comparison among the different mutations and the relationship with clinical characteristics was not performed. Finally, the mechanism underlying these gene mutations and the correlation with clinical indicators, especially patient staging, are not fully elucidated, which requires further in vitro and in vivo studies. 
Table 10 Relationship between mutation of PIK3CA gene in exon E20 and clinical parameters

\begin{tabular}{|c|c|c|c|c|c|c|c|}
\hline & \multirow[t]{2}{*}{ Clinical parameters } & \multirow[t]{2}{*}{ No. } & \multicolumn{2}{|c|}{ PIK3CA-E20 } & \multirow{2}{*}{$\begin{array}{l}\text { Positive } \\
\text { rate (\%) }\end{array}$} & \multirow[t]{2}{*}{$x^{2}$} & \multirow{2}{*}{$\begin{array}{l}p \\
\text { value }\end{array}$} \\
\hline & & & Wild type & Mutant type & & & \\
\hline \multirow[t]{2}{*}{ Age } & $\leq 60$ & 112 & 83 & 1 & 0.89 & 1.127 & 0.569 \\
\hline & $>60$ & 109 & 79 & 0 & 0 & & \\
\hline \multirow[t]{2}{*}{ Gender } & Male & 114 & 85 & 0 & 0 & 1.175 & 0.556 \\
\hline & Female & 107 & 77 & 1 & 0.93 & & \\
\hline \multirow[t]{3}{*}{ Sample type } & Tissue sample & 194 & 139 & 0 & 0 & 12.794 & 0.012 \\
\hline & Whole blood sample & 22 & 18 & 1 & 4.55 & & \\
\hline & Whole blood + tissue sample & 5 & 5 & 0 & 0 & & \\
\hline \multirow[t]{3}{*}{ Pathological type } & Squamous cell carcinoma & 15 & 12 & 0 & 0 & 4.735 & 0.578 \\
\hline & Adenocarcinoma & 155 & 112 & 0 & 0 & & \\
\hline & Adenosquamous carcinoma & 7 & 5 & 0 & 0 & & \\
\hline \multirow[t]{7}{*}{ Staging } & Stage IA & 22 & 16 & 0 & 0 & 8.351 & 0.870 \\
\hline & Stage IB & 51 & 36 & 0 & 0 & & \\
\hline & Stage IIA & 8 & 6 & 0 & 0 & & \\
\hline & Stage $\| B$ & 9 & 8 & 0 & 0 & & \\
\hline & Stage IIIA & 23 & 16 & 0 & 0 & & \\
\hline & Stage IIIB & 5 & 4 & 0 & 0 & & \\
\hline & Stage IV & 33 & 29 & 0 & 0 & & \\
\hline \multirow[t]{3}{*}{ Treatment } & Surgery & 67 & 51 & 0 & 0 & 5.927 & 0.431 \\
\hline & Chemotherapy & 37 & 25 & 1 & 2.70 & & \\
\hline & Surgery + chemotherapy & 66 & 50 & 0 & 0 & & \\
\hline
\end{tabular}

Data are adjusted for age, gender, sample type, pathological type, staging, and treatment method

\section{Conclusions}

EGFR, KRAS, and PIK3CA gene mutations have a correlation with the clinical characteristics of lung cancer patients, which should be further accepted and improved to enhance the efficacy for personalized cancer treatment.

\section{Abbreviations}

NSCLC: Non-small cell lung cancer; TKI: Tyrosine kinase inhibitor; EGFR: Epidermal growth factor receptor; PFS: Progression-free survival; PIK3CA: Phosphatidylinositol-3 kinase; PI3Ks: Phosphatidylinositol-3 kinase family; EXO-SAP: Exonuclease and alkaline phosphatase; ASPE: Allele-specific primer extension; MFI: Median fluorescence value; Hsp90: Heat shock protein 90

\section{Acknowledgements}

None.

\section{Authors' contributions}

SL was in charge of the study's conception and design. XJL conducted the clinical and experimental studies. All authors contributed to data acquisition and analysis. XJL wrote the manuscript, and SL reviewed the manuscript. The authors read and approved the final manuscript.

\section{Funding}

This study was funded by the Key Research and Development Program of Shaanxi [grant number 2020SF-101].

\section{Availability of data and materials}

The data and materials used or analyzed during the current study are available from the corresponding author upon reasonable request.

\section{Declarations}

\section{Ethics approval and consent to participate}

This study was approved by the Ethics Committee of The First Affiliated Hospital of Xi'an Jiaotong University. All patients gave informed written consent to participate in the study.

\section{Consent for publication}

Informed consent was obtained from all individual participants included in the study.

\section{Competing interests}

The authors declare that they have no competing interests.

Received: 28 December 2020 Accepted: 22 June 2021

Published online: 03 July 2021

\section{References}

1. Sung H, Ferlay J, Siegel RL, Laversanne M, Soerjomataram I, Jemal A, et al. Global Cancer Statistics 2020: GLOBOCAN estimates of incidence and mortality worldwide for 36 cancers in 185 countries. CA Cancer J Clin. 2021.

2. Torre LA, Siegel RL, Jemal A. Lung cancer statistics. Adv Exp Med Biol. 2016; 893:1-19. https://doi.org/10.1007/978-3-319-24223-1_1.

3. Ettinger DS, Wood DE, Aggarwal C, Aisner DL, Akerley W, Bauman JR, et al. NCCN guidelines insights: non-small cell lung cancer, version 1.2020. J Natl Compr Cancer Netw. 2019;17(12):1464-72. https://doi.org/10.6004/jnccn.2019.0059. 
4. Jemal A, Bray F, Center MM, Ferlay J, Ward E, Forman D. Global cancer statistics. CA Cancer J Clin. 2011;61(2):69-90. https:/doi.org/10.3322/caac.20107.

5. Li YQ, Zheng Z, Liu QX, Lu X, Zhou D, Zhang J, et al. Moesin as a prognostic indicator of lung adenocarcinoma improves prognosis by enhancing immune lymphocyte infiltration. World J Surg Oncol. 2021;19(1):109. https:// doi.org/10.1186/s12957-021-02229-y.

6. Feng $L$, Wang $Z$, Jing $L$, Zhou $Z$, Shi $S$, Deng $R$, et al. Recombinant human endostatin combined with chemotherapy for advanced squamous cell lung cancer: a meta-analysis. World J Surg Oncol. 2021;19(1):64. https://doi.org/1 0.1186/s12957-021-02161-1.

7. Magnuson WJ, Lester-Coll NH, Wu AJ, Yang TJ, Lockney NA, Gerber NK, et al. Management of brain metastases in tyrosine kinase inhibitor-naïve epidermal growth factor receptor-mutant non-small cell lung cancer: a retrospective multi-institutional analysis. J Clin Oncol. 2017;35(10):1070-7. https://doi.org/10.1200/JCO.2016.69.7144.

8. Khozin S, Blumenthal GM, Jiang X, He K, Boyd K, Murgo A, et al. U.S. Food and Drug Administration approval summary: erlotinib for the first-line treatment of metastatic non-small cell lung cancer with epidermal growth factor receptor exon 19 deletions or exon 21 (L858R) substitution mutations. Oncologist. 2014; 19(7):774-9. https://doi.org/10.1634/theoncologist.2014-0089.

9. Zhang $X$, Jiang $Y, Y u H$, Xia $H$, Wang $X$. A comprehensive study on the oncogenic mutation and molecular pathology in Chinese lung adenocarcinoma patients. World J Surg Oncol. 2020;18(1):172. https://doi. org/10.1186/s12957-020-01947-z.

10. Herbst RS, Tsuboi M, John T, Grohé C, Majem M, Goldman JW, et al. LBA5 Osimertinib as adjuvant therapy in patients (pts) with stage IB-IIIA EGFR mutation positive (EGFRm) NSCLC after complete tumor resection: ADAURA. J Clin Oncol. 2020;38.

11. Rosell R, Carcereny E, Gervais R, Vergnenegre A, Massuti B, Felip E, et al. Erlotinib versus standard chemotherapy as first-line treatment for European patients with advanced EGFR mutation-positive non-small-cell lung cancer (EURTAC): a multicentre, open-label, randomised phase 3 trial. Lancet Oncol. 2012;13(3):239-46. https://doi.org/10.1016/S1470-2045(11)70393-X.

12. Goncalves MD, Hopkins BD, Cantley LC. Phosphatidylinositol 3-kinase, growth disorders, and cancer. N Engl J Med. 2018;379(21):2052-62. https:// doi.org/10.1056/NEJMra1704560.

13. Anderson GR, Wardell SE, Cakir M, Crawford L, Leeds JC, Nussbaum DP, et al. PIK3CA mutations enable targeting of a breast tumor dependency through mTOR-mediated MCL-1 translation. Sci Transl Med. 2016;8(369):369ra175.

14. Song Z, Yu X, Zhang Y. Mutation and prognostic analyses of PIK3CA in patients with completely resected lung adenocarcinoma. Cancer Med. 2016; 5(10):2694-700. https://doi.org/10.1002/cam4.852.

15. Wang L, Guo Q, Yu W, Qiao L, Zhao M, Zhang C, Hu X, Yang G, Xiong L, Lou J. Quantification of plasma EGFR mutations in patients with lung cancers: Comparison of the performance of ARMS-Plus and droplet digital PCR. Lung Cancer. 2017;114:31-7.

16. Ou SHI, Nagasaka M, Zhu WW. Liquid Biopsy to Identify Actionable Genomic Alterations. Am Soci Clin Oncol Educ Book. 2018;(38):978-97.

17. Joyce DP, Murphy D, Lowery AJ, Curran C, Barry K, Malone C, et al. Prospective comparison of outcome after treatment for triple-negative and non-triple-negative breast cancer. Surgeon. 2017;15(5):272-7. https://doi. org/10.1016/j.surge.2016.10.001.

18. Li P, Li Y, Ma L. Potential role of chimeric genes in pathway-related gene co-expression modules. World J Surg Oncol. 2021;19(1):149. https://doi.org/1 0.1186/s12957-021-02248-9.

19. Ding Y, Liu N, Chen M, Xu Y, Fang S, Xiang W, et al. Overexpressed pseudogene MT1L associated with tumor immune infiltrates and indicates a worse prognosis in BLCA. World J Surg Oncol. 2021;19(1):133. https://doi. org/10.1186/s12957-021-02231-4.

20. Han B, Tjulandin S, Hagiwara K, Normanno N, Wulandari L, Laktionov K, et al. EGFR mutation prevalence in Asia-Pacific and Russian patients with advanced NSCLC of adenocarcinoma and non-adenocarcinoma histology: the IGNITE study. Lung Cancer. 2017;113:37-44. https://doi.org/10.1016/j.lungcan.2017.08.021.

21. Barlesi F, Mazieres J, Merlio JP, Debieuvre D, Mosser J, Lena $H$, et al. Biomarkers France contributors. Routine molecular profiling of patients with advanced non-small-cell lung cancer: results of a 1-year nationwide programme of the French Cooperative Thoracic Intergroup (IFCT). Lancet. 2016;387(10026):1415-26. https://doi.org/10.1016/S0140-6736(16)00004-0.

22. Yang Z, Hackshaw A, Feng Q, Fu X, Zhang Y, Mao C, et al. Comparison of gefitinib, erlotinib and afatinib in non-small cell lung cancer: a metaanalysis. Int J Cancer. 2017;140(12):2805-19. https://doi.org/10.1002/ijc.30691.
23. Robichaux JP, Elamin YY, Tan Z, Carter BW, Zhang S, Liu S, et al Mechanisms and clinical activity of an EGFR and HER2 exon 20-selective kinase inhibitor in non-small cell lung cancer. Nat Med. 2018;24(5):638-46. https://doi.org/10.1038/s41591-018-0007-9.

24. Wu YL, Tsuboi M, He J, John T, Grohe C, Majem M, et al. Osimertinib in resected EGFR-mutated non-small cell lung cancer. N Engl J Med. 2020; 383(18):1711-23. https://doi.org/10.1056/NEJMoa2027071.

25. Vyse S, Huang PH. Targeting EGFR exon 20 insertion mutations in non-small cell lung cancer. Signal Transduct Target Ther. 2019;4(1):5. https://doi.org/1 0.1038/s41392-019-0038-9.

26. Nie Y, Gao W, Li N, Chen W, Wang H, Li C, et al. Relationship between EGFR gene mutation and local metastasis of resectable lung adenocarcinoma. World J Surg Oncol. 2017;15(1):55. https://doi.org/10.1186/s12957-017-1103-X.

27. Shi Y, Au JS, Thongprasert S, Srinivasan S, Tsai CM, Khoa MT, et al. A prospective, molecular epidemiology study of EGFR mutations in Asian patients with advanced non-small-cell lung cancer of adenocarcinoma histology (PIONEER). J Thorac Oncol. 2014;9(2):154-62. https://doi.org/10.1 097/JTO.0000000000000033.

28. Hernandez-Arenas LA, Lin L, Yang Y, Liu M, Guido W, Gonzalez-Rivas D, et al. Initial experience in uniportal subxiphoid video-assisted thoracoscopic surgery for major lung resections. Eur J Cardiothorac Surg. 2016;50(6):10606. https://doi.org/10.1093/ejcts/ezw189.

29. Mortazavi F, Lu J, Phan R, Lewis M, Trinidad K, Aljilani A, et al. Significance of KRAS/PAK1/Crk pathway in non-small cell lung cancer oncogenesis. BMC Cancer. 2015;15(1):381. https://doi.org/10.1186/s12885-015-1360-4.

30. Saito M, Shiraishi K, Kunitoh H, Takenoshita S, Yokota J, Kohno T. Gene aberrations for precision medicine against lung adenocarcinoma. Cancer Sci. 2016;107(6):713-20. https://doi.org/10.1111/cas.12941.

31. Peng J, An S, Wang HP, Chen XL, Ning XG, Liu J, et al. Video-assisted thoracoscopic surgery lobectomy for lung cancer versus thoracotomy: a less decrease in sVEGFR2 level after surgery. J Thorac Dis. 2016;8(3):323-8. https://doi.org/10.21037/jtd.2016.02.16.

32. Roberts PJ, Stinchcombe TE, Der CJ, Socinski MA. Personalized medicine in non-small-cell lung cancer: is KRAS a useful marker in selecting patients for epidermal growth factor receptor-targeted therapy? J Clin Oncol. 2010; 28(31):4769-77. https://doi.org/10.1200/JCO.2009.27.4365.

33. Jhaveri K, Ochiana SO, Dunphy MP, Gerecitano JF, Corben AD, Peter Rl, et al. Heat shock protein 90 inhibitors in the treatment of cancer: current status and future directions. Expert Opin Investig Drugs. 2014;23(5):611-28. https:// doi.org/10.1517/13543784.2014.902442.

34. Keppler-Noreuil KM, Parker VE, Darling TN, Martinez-Agosto JA. Somatic overgrowth disorders of the PI3K/AKT/mTOR pathway \& therapeutic strategies. Am J Med Genet C: Semin Med Genet. 2016;172(4):402-21. https://doi.org/10.1002/ajmg.c.31531.

35. McGowan M, Hoven AS, Lund-Iversen M, Solberg S, Helland $\AA$, Hirsch FR, et al. PIK3CA mutations as prognostic factor in squamous cell lung carcinoma. Lung Cancer. 2017;103:52-7. https://doi.org/10.1016/j.lungcan.2016.11.018.

36. Miron A, Varadi M, Carrasco D, Li H, Luongo L, Kim HJ, et al. PIK3CA mutations in in situ and invasive breast carcinomas. Cancer Res. 2010;70(14): 5674-8. https://doi.org/10.1158/0008-5472.CAN-08-2660.

\section{Publisher's Note}

Springer Nature remains neutral with regard to jurisdictional claims in published maps and institutional affiliations.

Ready to submit your research? Choose BMC and benefit from:

- fast, convenient online submission

- thorough peer review by experienced researchers in your field

- rapid publication on acceptance

- support for research data, including large and complex data types

- gold Open Access which fosters wider collaboration and increased citations

- maximum visibility for your research: over $100 \mathrm{M}$ website views per year

At BMC, research is always in progress.

Learn more biomedcentral.com/submissions 